\title{
LOCATION OF HARBORS
}

Kenneth P. Peel

Special Assistant, Planning and Reports Branch

Los Angeles District, Corps of Engineers

Department of the Army

Los Angeles, Calufornia

\section{INTRODUCTION}

The location of harbors is dependent on many factors, which vary widely in different parts of the country. For example, along the Atlantic coast are many natural waterways. The improvement of these waterways, especially for small craft, is comparatively inexpensive and harbors are constructed at frequent intervals. However, along the coast of southern California, natural facilities are almost nonexistent. Consequently, improvements are farther apart and correspondingly larger. The cost per boat accommodated remains about the same. In general, this discussion is based on conditions along the coast of California, particularly southern Cal1fornia.

The purpose of this paper is to show how the costs, functions, types, sizes, and physical features of harbors and the effect of harbors on adjacent shore lines and underground basins are related to the selection of a proposed harbor site. Typical examples, with brief discussions of the principal factors involved in the selection of harbor sites, are given later in this paper.

\section{FUNCTIONS OF HARBORS}

In general, public harbors may be divided into four classifications according to the function the harbor is designed to fulfill. These are: commercial, recreational, and flshing harbors, and harbors of refuge. Harbors used exclusively for military or naval use are not included in this discussion. Also, it must be recognized that many harbors have multiple uses that include elements of all four classifications in varying degrees. The selection of any harbor location is directly affected by the function that the harbor is designed to fulfili. This, of course, presupposes that a need exists for the particular kind of harbor considered.

For example, the commercial harbor should be so located as to best expedite the movement of goods, and should be so designed as to be readily adaptable for future expansion of both land and water facilities. The history of all our major ports is one of continued expansion and improvement. However, a harbor of refuge is a haven where vessels may seek shelter in heavy weather or may obtain emergency supplies and repairs. This type of harbor is generally in more remote sections of the coast, and emphasis is placed on so locating the harbor as to provide a safe entrance during severe storms. The selection of a location for a fishing harbor is governed by proximity to fishing grounds, adequate housing for fishermen, service facilities for flshing boats, and markets for fish caught.

\section{TYPES OF HARBORS}

Harbors are either natural or artificial. If a harbor is natural, 1ts location is determined and only its most efficient use or improvement must be ascertained. In early days, communities grew up around these natural harbors and harbor improvements came about as natural processes.

Artificial harbors are generally developed to fulfill specific needs. These harbors may be either offshore facilities or interior basins, depending on location and natural terrain. Where conditions permit, a harbor with entrance jetties and interior basins is the most satisfactory. However, because of prohibitive rights-of-way costs or of rugged terrain, dredging an interior harbor is often impracticable, and an offshore harbor protected by a breakwater system or a combination of natural headlands and breakwaters must be constructed. Each type of harbor has 1ts own inherent advantages and disadvantages, which must be weighed before selection of the location for a proposed harbor. If the location of the 
harbor has been otherwise determined, this location may govern the selection of the type of harbor.

\section{DETERMINING THE BEST LOCATION FOR HARBORS}

Careful consideration is given to many factors in determining the best location for a harbor. Some of these factors are general and aid in determining whether a harbor should be provided in a general locality. Others are specific and ald in pin-pointing the location of a harbor or even the location of components of the harbor. These factors are all interrelated and must be compared with one another to determine the relative weight each factor may have in a specific case. Major factors are briefly discussed in the following paragraphs.

\section{POPULATION CENTERS}

Except harbors for refuge only, harbors generally should be near large centers of population. This is particularly important for commercial harbors where a nearby outlet for consumer goods results in lower transihipment costs. The costs of both imports and exports are affected by the overland shipping distances involved. This was one argument advanced by the proponents of a harbor at Santa Monica against a harbor at San Pedro. Large population centers also provide manufactured products for export and a labor market of dock and ship workers.

Recreational harbors also should be near large centers of population or should be combined with commerclal fishing harbors and harbors of refuge to be fustified. The basic protection for an artificlal harbor is so expensive that it is warranted only if a large number of boats use the harbor. These boats can only be provided by a large tributary population.

For commerclal fishing harbors, proximity to large population centers is a factor but not so important as it once was. The present practice of quick freezing permits a longer period for distribution, and quick sales to the consumer are not mandatory. However, a large nearby population reduces handling costs and provides labor for canneries and fisheries.

\section{REQUIREMENTS OF FISHING}

Requirements vary for different types of fishing. Tuna clippers, which are large boats equipped with refrigeration, travel long distances for tuna. Because their catch must be sold to canneries, they generally operate from the nearest commercial harbor. Smaller boats, which are not equipped with refrigeration, fish for sardines and pilchard. Because these fish spoil rapidly, the boats must be unloaded not later than the day after the fish are caught. Accordingly, the fishing radius for this type of fishing is more limited and harbors are required at more frequent intervals. The hook-and-line fishermen who supply the market with fresh fish operate smali one- or two-man boats that have a very limited safe cruising radius. Unless harbors are provided at distances of not over 15 to 20 miles from the fishing grounds, those grounds cannot be exploited. Along the coast between Morro Bay and Monterey Bay are many such unexploited fishing grounds. The State of California Division of Fish and Game has requested that consideration be given to the development of an adequate number of harbors in this reach of coast line.

\section{DISTANCE BETWEEN HARBORS}

Studies are now being made to determine the need for a chain of small-craft harbors along the coast of Californta and also to determine whether these harbors can be economically justified. They would be spaced at intervals that would permit a boat at no time to be more than 2 or 3 hours from a haven of refuge. As a result, harbors would be about $30 \mathrm{miles}$ apart. A harbor proposed between two existing harbors 50 to 70 miles apart would be about halfway between the two existing harbors, providing a satisfactory location was avallable. If the existing harbors were 80 to 100 miles apart, two harbors probably would be developed, or, if only one could be justifled at the time, it probably would be about one-third of the distance from one of the existing harbors. 


\section{LOCATION OF HARBORS}

\section{TRIBUTARY AREAS}

The tributary area to any harbor is primarily determined by the access routes to that harbor as compared with those to other adjacent harbors. Other factors, such as labor or through rates, may sometimes be of more importance. For example, cotton has been shipped by rail from the Sacramento and San Joaquin Valleys to Galveston or other Texas ports and then shipped to the Orient via the Panama Canal. This cotton should have been shipped through San Francisco Bay. Westcoast ports are making every effort to eradicate the conditions that lead to such an abnormal distortion of normal tributary areas.

Owners of small craft live not only in population centers immediately adjacent to harbors for small craft but also in distant communities. Many residents of Bakersfield now keep their boats at Los Angeles and Long Beach Harbors. Because Bakersfield is considerably closer to Ventura than to Los Angeles, residents of Bakersfield probably would keep their boats at Ventura if adequate facilities were available. The needs of an entire back tributary area must be considered in determining the location of a new harbor or the necessity for improvements at existing harbors.

\section{ACCESS ROADS}

Access roads, both rall and highway, are important considerations in determining the extent of a tributary area and the most favorable location for a harbor. Included under this heading is the necessary relocation of highways and highway bridges. This presents a serious problem in the consideration of the proposed small-craft harbor at Alamitos Bay, where a secondary highway over a trestle bridge crosses the entrance channel and a rallroad crosses the site of the central part of the proposed harbor. A considerable readjustment of access roads would be required to properly serve the harbor area.

Access roads are important because owners of boats and suppliers of service to boats must be able to reach them from the land side. This is a major problem in determining the best location for harbors of refuge near point conception and Point Arguelio, where the local sponsoring agencies probably would have to provide several miles of access highways. Even where adequate access roads exist, they affect the location of a harbor. Every effort is made to select that location where the greatest benefit would result to the greatest number of people and where the use of existing facilities would not be adversely affected.

\section{SIZE REQUIREMENTS}

In southern California, basic protection at a very high cost generally must be provided for any proposed harbor. Also, harbors must be larger and farther apart than east-coast harbors to be economically justified. S1ze is sometimes a decisive factor in determining the location of a harbor. For example, Playa del Rey is the only sultable location in Los Angeles County for a small-craft harbor of the size proposed. At one time local interests at Laguna Beach requested consideration of a harbor in a small canyon between Laguna and South Laguna. However, the request was withdrawn when they realized that the available space was entirely inadequate.

Important considerations in the work of planning and designing a harbor include selecting the location of the entrance and determining its size. A harbor entrance should be of sufficient width to accommodate anticipated traffic with ease and safety. It should not be so wide as to induce shoaling between the jetties and the attendant development of a meandering channel. In southern cal1fornia, the tidal prism of a harbor is never sufficient to maintain the entrance naturally. Accordingly, the wider the entrance, the longer must be the entrance jetties to prevent shoaling.

In planning an entrance channel to upper Newport Bay, local interests were faced with a cholce between the Balboa Island channel and the Upper Bay channel. The Balboa Island channel between the upper bay and the ocean would be a shorter channel and would reduce traffic congestion in the lower bay. However, because of ledge rock and high rocky bluffs, local interests have expressed the opinion that 


\section{COASTAL ENGINEERING}

a channel entrance of adequate width through the Balboa Island channel would be neither practicable nor economically feasible.

\section{SURGE}

Surge is generaliy a major factor in determining the location of the integral parts of a harbor rather than in determining the location of the harbor itself (see chapter 6). The causes of surge are quite complex and individually may have some bearing in detemining the location of a harbor. Short-period waves seldom cause surge. They could only do so if the basin were of such shape and size as to develop a period of resonance that would combine a damping and amplifying effect on waves of certain short periods. Generally, the surge results from a convergence of long-period waves. In determining the location of a harbor entrance, areas of concentrated long-period waves are carefully avolded if possible.

Model studies are often made to determine the best locations for component parts of a harbor so that surge will be reduced the greatest practicable extent. A model study was made by the United States Waterways Experiment Station at Vicksburg, Miss., for the Long Beach Harbor Department to assist Long Beach in the planning and layout of its East Basin (see Chapter 23). As a result of this study, major changes were made in the location of the basin entrance and in the layout of the interior basin. Data obtained from the model study indicated that these modifications would materially reduce surge in the new basin. Similar studies were made for the Los Angeles District to determine the proper length and location of a proposed detached breakwater extension to reduce surge and wave action in Anaheim Bay Harbor.

In Los Angeles Harbor, a surge condition exists in East and West channels and in slip 230 on Terminal Island. If a model study had been made when the harbor was belng planned, this surge condition $\mathrm{might}$ have been reduced or eliminated.

\section{PHYSICAT, FEATURES}

The importance of physical features in determining the best location for a harbor is readily apparent. These features, which include natural protection, availability of land for service areas, natural sloughs for harbor development, streams, and drainage, outweigh all other considerations. This is reasonable because the physical features of a coast Ilne affect the many other factors that must be considered before a harbor is constructed.

The planner and designer must fully utilize all natural protection that would help to provide a less expensive and a safer harbor. Use of natural sloughs would reduce costs of rights-of-way and of dredging. Southern California streams, which are dry most of the year, do not augment the tidal prism in maintaining an entrance channel. During flood periods these streams often carry large quantities of debris that shoal interior basins and channels. Diversion of streams may be difficult and expensive. Drainage sometimes is a problem, especlally where a harbor is constructed in low marshland. Filling sufficient ground around the harbor for its service and operation may result in drainage problems in the rest of the low-1ying areas.

\section{EFFECT ON THE ADJACENT SHORE LINE}

Along the coast of California, sand movement is generily from up coast to down coast or north to south. Minor exceptions occur at major headlands, where the direction of the coast Iine produces localized areas of up-coast drift, and at many small pocket beaches. Also, a general reversal of the normal trend of sand movement occurs during periods of southern swell. The construction of offshore breakwater or harbor entrance jetties results in interception of this down-coasttrending littoral drift and in accretion on the up-coast side and erosion on the down-coast side. This process continues unt1l the harbor is filled or until sand passes around the jetties, shoaling the entrance channel as it passes. If nothing is done, the process eventualiy ends but the harbor is no longer navigable. In the meantime, millions of dollars in damage may occur to down-coast areas.

This danger has been recognized for some time. The corps of Engineers is required to consider the effects that any proposed harbor would have on adjacent 
beaches for a distance of $10 \mathrm{miles}$ on both sides of the harbor. The damage is small in isolated or rugged areas but is of primary importance in improved areas with population centers and popular beaches. The necessity for bypassing of sand past the harbor entrance to maintain the harbor's navigability and to prevent damage to down-coast beaches by maintaining the normal flow of littoral drift is always given careful consideration. The cost of bypassing of sand is included in the costs of the project. A cholce in location may occaslonally occur to minimize the danger of erosion damage. For example, a survey was recommended for a harbor at Malibu instead of at Point Dume because Malibu was down coast from the highly developed beach colony and any improvements probably would not cause erosion of this valuable area.

\section{WAVE EXPOSURE}

Wave exposure is always considered in determining the location of a harbor and of the integral parts of a harbor, especially the entrance channel. By the use of refraction diagrams, zones of convergence and divergence may be readily determined. With these zones established, the harbor entrance can be so located as to provide optimum safe navigating conditions. A slight shift in location often will result in lowering the design wave several feet. Thus, the size of protective structures may be safely reduced with resultant savings in cost.

An example of a poorly located structure subject to wave exposure is the Standard 011 Co. pier at El Segundo. The pier is opposite a submerged ridge at about the 12-fathom depth. Long-period waves (18 sec.) from the northwest are affected by this ridge, which causes them to converge near the pier. Because of this convergence, waves more than $20 \mathrm{ft}$. In height have been observed at the pier when wave helghts a short distance on both sides of the pler were not more than $6 \mathrm{ft}$. In height. Company officials state that if as much had been known about wave refraction when the pler was built as is now known, the pier would have been built elsewhere. At Redondo Beach a study of refraction diagrams resulted in a slight change in the location of the breakwaters with a marked reduction in wave exposure at the entrance. The masking effect of islands in reducing wave heights is considered in determining the location of a harbor and the height of the design wave.

\section{SALINE CONTAMINATION}

The problem of saline contamination is especially important in southern California when considering an interior harbor such as Playa del Rey or a ship channel such as proposed at Laguna Dominguez. At Playa del Rey, a geological study of underground aquifers indicates that the proposed dredging would not increase the saline contamination of ground water. However, in other instances the introduction of salt water to inland areas by channel dredging might cause damaging saline contamination of extensive underground basins. Extensive studies have been made to alleviate the salt-water intrusion in the lower reaches of the Sacramento River.

\section{REQUIREMENTS OF LOCAL COOPERATION}

Authorization of a harbor project by congress is usually contingent on local interests' bearing a substantial part of the cost of the proposed harbor. The allocation of costs between the Federal Government and local interests is based on policles established for different types of harbors. In general, local interests are required to bear the costs of rights-of-way; utilities, bridges, and highways, including their relocation; slips, moorings, and all other facilities for servicing small craft; piers, wharves, transit sheds, and allied structures in commercial harbors; dredging for slips and for mooring areas; landscaping; and administration bulldings. Local interests are also required to assume the cost of any damage resulting from construction of the project. Other special requirements may be included as conditions warrant.

The willingness of local interests to assume their share of the cost of a project is sometimes the deciding factor in determining the location of a harbor, especially where a choice exists between two favorable sites. Under most circumstances, the harbor probably would be located at the site where local interests were willing and able to comply with the requirements of local cooperation. For example, a cholce existed between Plerpont Bay and Port Hueneme as sites for a 


\section{COASTAL ENGINEERING}

small-craft harbor in Ventura County. Pierpont Bay had widespread support in Ventura county until it became known that a harbor at Pierpont Bay would require bypassing of sand twice instead of once. The knowledge that either the city of Ventura or Ventura County would have to assume the cost of the second bypassing, which was estimated at $\$ 125,000$ a year, eliminated Pierpont Bay from further consideration and concentrated support for a harbor at Port Hueneme.

\section{NATIONAT DEFENSE}

National defense is also an important consideration where a choice exists between two sites. It may even be the deciding factor in determining whether a harbor will be justified. The fact that one site was militarily more important than the second site would lead to either the elimination of the site with less military importance or to the construction of both harbors, should such action be found necessary and justified.

\section{COSTS}

With the exception of national defense, all factors discussed and all solutions of the problems they present are related to the cost of the project. They may affect costs of construction, rights-of-way, and maintenance. Where a choice exists between sites, the site that would provide adequate facilities and that would be economically the most feasible probably would be the site selected. A comparison of costs for various sites is made by reducing costs including amortization, interest on investment, operation, and maintenance to an annual basis.

\section{APPLICATION OF THE FOREGOING FACTORS TO THE SELECTION OF SPECIFIC HARBOR SITES}

As previously stated, the final selection of a harbor site is dependent on a combination of factors, although some may be more important than others. To illustrate how the importance of these primary factors varies at different sites, their effect on proposed harbors either under consideration or already authorized is briefly discussed in the following paragraphs.

The Cambria site was selected for further study mostly because of the requirements of fishing. Principal secondary factors were the proximity of population centers and the distance from existing harbors. The alternative site at San Simeon was selected because of the physical features of natural protection.

The improvement at Morro Bay resulted primarily from the bay's importance to national defense as well as its favorable physical features. Morro Bay is one of the few natural bays in southern California.

The coxo anchorage site would be a harbor of refuge only. The site was selected for further study because of the distance between existing harbors and because of the natural protection at the site.

Port Hueneme was recommended for construction because of the effects of other proposed harbors in that vicinity on the adjacent shore line and also because of the needs of the tributary area.

The proposed Playa del Rey Harbor was recommended because (1) the site is near the largest concentration of population on the west coast; (2) ample space is avaliable for a harbor of the proposed capacity; (3) the land has comparat1vely Iittle value except for a harbor; and (4) rights-of-way costs, although high, would be relatively low for an area of its size close to the center of population.

Primary factors leading to the adoption of a project at Redondo Beach were (1) the effect of the project on the adjacent shore line and (2) the peculiar conditions of wave exposure. The head of a submarine canyon is in the vicinity of Horseshoe pier in Redondo Beach. Ten-second waves refract over the banks of the canyon in such a manner as to converge on the beach between Diamond street and Fifth Place with highly destructive effects. At the same time, the divergence that occurs over the submarine canyon tends to create a zone of calm water at the proposed entrance. The proposed offshore breakwater would intercept the waves before converging and obviate the necessity for an extremely heavy breakwater section. 


\section{LOCATION OF HARBORS}

The site of Mission Bay Harbor, which is now under construction, was selected principally because of its favorable physical features. Mission Bay was a large natural bay being shoaled by depositions from San Diego River. A major factor in the authorization of this project was the voting of bonds by residents of the City of San Diego to meet the requirements of local cooperation before adoption of the project by Congress. The river is now being channelized direct to the ocean, and the bay is being dredged.

\section{CONCLUSION}

The foregoing comments may be summarized in the following conclusions:

a. Factors affecting the location of any harbor are many and vary at each site.

b. The location is seldom determined by any one factor, but by weighing the importance of many factors or combinations of factors.

c. No mathematical formula exists for solving harbor problems. Answers cannot be obtained by tossing these factors into a hopper and turning a crank.

d. Many aids, such as wave hindcasting from historical weather maps and construction of refraction and diffraction diagrams, have been developed recently for the determination of proper location. This research is still in progress.

e. Despite our scientific advancements, experience in analyzing the results of our studies is still the first requisite in determining the most favorable location for a harbor and the best plan for its optimum development. 